\title{
Evaluation of in vitro antioxidant and antimicrobial activity of polyherbal formulation of Thirikadugu chooranam and Parangipattai chooranam
}

\author{
P.P. Sethumathi , K.Manjuparkavi*, V. Lalitha, T. Sivakumar, M.Menaka*, A.Jayanthi** and B.Ashok Kumar*** \\ Nandha College of Pharmacy, Erode-638052, Tamilnadu, India \\ * Nandha Siddha Medical College and Hospital, Erode-638052, Tamilnadu, India \\ ** Child Health Nursing, Nandha College of Nursing, Erode-638052, Tamilnadu, India \\ *** Nandha Engineering College, Erode-638052, Tamilnadu, India
}

\section{Article Info}

\section{Article history}

Received 17 October 2021

Revised 7 December 2021

Accepted 10 December 2021

Published Online 30 December 2021

\section{Keywords}

Thirikadugu chooranam

Parangipattai chooranam

Organoleptic characters
Antimicrobial activity

Secondary phytoconstituents

\begin{abstract}
Traditional systems of medicine are widely practiced in many countries. For a wide variety of human ailments, plant materials are being emphasized to be used as a source of medicine because of the following reasons, population rise, poor supply of drugs, expenditure of treatments, adverse effects of several synthetic drugs and increase resistance to infectious organisms for presently used drugs. Therefore, the current study highlights the organoleptic characters, phytochemical analysis, radical scavenger (antioxidant) activity and antimicrobial properties of two polyherbal formulations, Thirikadugu Chooranam (TC) made of dry ginger (Zingiber officinalae), black pepper (Piper nigrum), long pepper (Piper longum) and Parangipattai Chooranam (PC) made of Parangipattai (Smilax chinensis) and Karunthulasi (Ocimum tenuiflorum). The antibacterial activity against the gram-positive, gram-negative bacteria and antifungal activity of both the herbal formulations were determined. Radical scavenging activities of TC and PC were determined by various methods. TC showed good radical scavenging activity than PC, whereas, PC showed significant antibacterial activity than TC. Phenols and its derivatives might be responsible for high antioxidant property in TC Presence of various secondary phytoconstituents in PC could be the reason for eliminating bacteria and fungi.
\end{abstract}

\section{Introduction}

Infectious diseases remain a major global public health threat worldwide and extend their violent domain with each passing day of the week and are mass killers, with the populations in poor countries being hit the hardest. Herbal medicines are the primary medicine to treat infection in some developing countries. The extracts of herbal materials imply constant attempts to explore novel phytocompounds with prospective antimicrobial activity. Many of the herbal medicines are sources of diverse molecules which exhibit radical scavenging and antimicrobial properties that defend the human body against pathogens and also cellular oxidation reactions. Therefore, they are significant in producing diverse forms of herbal medicine for their antimicrobial, antiviral and antioxidant potential. Several complications occur by the use of antibiotics and other anti-infective agents for the treatment of transmittable diseases. The main predominant complication is the production of free radicals called as reactive oxygen species (ROS). ROS are very toxic and have been thought to play a main role in producing cancer (Nakamura et al., 2017; Parham et al., 2019; Simoes et al.,2018; Jothivel et al., 2007).

Recently, the natural material has become superlative treatment for microbial infections. The application of herbal materials would be

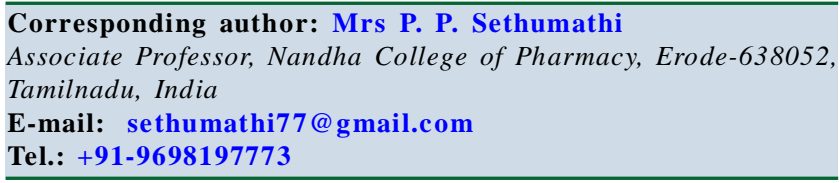

Copyright (c) 2021 Ukaaz Publications. All rights reserved.

Email: ukaaz@yahoo.com; Website: www.ukaazpublications.com an ideal alternative and can also open up a new chance in creating new preparations with lower side effects (Torkan et al., 2015; Tribess et al., 2015). Indigenous traditional medicines are very effective with their therapeutic values, but they lack in standardization, it is required to develop the standardization technique. The present investigation highlights the organoleptic, qualitative phytochemical, antimicrobial and radical scavenger (antioxidant) properties of indigenous polyherbal formulations (Thirikadugu chooranam and Parangipattai chooranam) used in the treatment of respiratory diseases.

\section{Materials and Methods}

Thirikadugu chooranam and Parangipattai chooranam were collected from Outpatient Department of Nandha Siddha Medical College and Hospital, Erode-52. The ingredients of Thirikadugu chooranam are dry ginger (Zingiber officinale), black pepper (Piper nigrum), long pepper (Piper longum) and Parangipattai chooranam has two herbal ingredients, namely; Parangipattai (Smilax chinensis) and Karunthulasi (Ocimum tenuiflorum). Initially, organoleptic characters like appearance, colour, taste and odour of polyherbal formulations were noted using traditional and standard techniques.The preliminary qualitative phytochemical screening was done following the standard procedure.

\subsection{Extract preparation}

Each formulation was extracted with $250 \mathrm{ml}$ of methanol and incubated for $24 \mathrm{~h}$ in a conical flask. After that, filter paper was used to filter the extract. The filtrates were dried in vacuo (freeze drier-Christ Alpha 2-4 LD Plus, Germany) and used for future research. 


\subsection{The preliminary phytochemical screening test}

The preliminary phytochemical screening test was carried out for each extracts of the samples as per the standard procedure (Kokate, 2002).

i. Detection of alkaloids: Extract was taken and dissolved in dilute hydrochloric acid and filtered.

Wagner's test: Filtrate $(2 \mathrm{ml})$ was treated with Wagner's reagent. Brown or reddish precipitate indicates the presence of alkaloids in the extract.

\section{ii. Detection of saponins}

Foam test: Extract was diluted to $20 \mathrm{ml}$ distilled water and shaken for $15 \mathrm{~min}$ in a graduated cylinder. Development of 1 centimeter layer of foam shows the presence of saponins.

\section{iii. Detection of phytosterols}

Salkowski's test : Extract was treated with chloroform and filtered and added few drops of concentrated sulphuric acid, shaken and allowed to stand for few minutes. Formation of reddish brown colour at the interface shows positive for triterpenoids.

\section{iv. Detection of phenols}

Ferric chloride test : Extract $(2 \mathrm{ml})$ was treated with few drops of ferric chloride solution. Appearance of bluish black colour shows the presence of phenols.

\section{v. Detection of tannins}

Gelatin test: When $1 \%$ gelatin solution containing sodium chloride was added to the extract, a white precipitate formed, indicating the presence of tannins.

\section{vi. Detection of flavonoids}

Alkaline reagent test: Extract was treated with few drops of $10 \%$ sodium hydroxide, intense yellow colour is formed then on addition of diluted hydrochloric acid it, becomes colourless, it indicates the presence of flavonoids.

\subsection{Pharmacological evaluation}

\subsubsection{DPPH radical scavenging activity}

The antioxidant property of methanol extracts of the formulation was analyzed using DPPH radical scavenging assay, as reported (Sanchez-Moreno et al., 1998.). Various concentrations (1000, 2000, $3000,4000,5000 \mathrm{mg} / \mathrm{l})$ of extract $(100 \mathrm{l})$ were mixed to $0.9 \mathrm{ml}$ of DPPH $(2.5 \mathrm{mg} / 100 \mathrm{ml})$ methanolic solution and the reactants were incubated at room temperature for $30 \mathrm{~min}$ in the dark. In the comparison group, distilled water was used instead of extract. The absorbance of the extract was measured at $515 \mathrm{~nm}$ with a spectrophotometer after $30 \mathrm{~min}$, and the radical scavenging activity was computed and expressed as a percentage.

\subsubsection{Superoxide radical scavenging activity}

The ability of the extract to scavenge the superoxide anion radical was determined (Zhishen et al., 1999). In phosphate buffered saline, $3 \times 10^{-6} \mathrm{M}$ riboflavin, $1 \times 10^{-2} \mathrm{M}$ methionine, $1 \times 10^{-4} \mathrm{M}$ nitro blue tetrozolium chloride, and $0.1 \mathrm{mM}$ EDTA were used to make the reaction mixture ( $\mathrm{pH} 7.4$ ). $3.0 \mathrm{ml}$ of the reaction mixture was combined with 1001 of extract in closed tubes and lit for $40 \mathrm{~min}$ under a fluorescent lamp for the analysis $(18 \mathrm{~W})$. The absorbance was then measured at $560 \mathrm{~nm}$ against the unilluminated reaction mixture. The results are expressed as a percentage of superoxide radical scavenging activity.

\subsubsection{Hydrogen peroxide scavenging activity}

The effect of extract on hydrogen peroxide was investigated using the method (Ruch et al. 1989). In $0.1 \mathrm{M}$ phosphate buffer, the extract $(100 \mathrm{ml})$ was combined with $5 \mathrm{ml}$ of $45 \mathrm{mM}$ hydrogen peroxide solution ( $\mathrm{pH}$ 7.4). The absorbance was measured at 230 $\mathrm{nm}$ after the reaction mixture was vortexed and incubated for 30 min at room temperature. A calibration curve was utilized to calculate the level of hydrogen peroxide left in the solution using the extract with phosphate buffer as a blank. The extract's hydrogen peroxide inhibition effect was calculated and represented as a percentage.

\subsubsection{Antimicrobial activity}

The herbal extract was investigated for in vitro antimicrobial activity at the concentration $(250,500$, and $1000 \mu \mathrm{g} / \mathrm{ml})$ against two gramnegative bacteria, Escherichia coli, Pseudomonas aeruginosa, two gram positive bacteria, Staphylococcus aureus, Bacillus subtilis and the antifungal activity against Candida albicans, Aspergillus niger. Agar plate diffusion method was used with Muller Hinton agar (bacteria) and Sabourand's dextrose agar (fungi) medium. The different tested micro-organism cultures were incubated at $30^{\circ} \mathrm{C}$ for $24 \mathrm{~h}$ with agar media. The diameter of the zone of inhibition around the well for antimicrobial activity was determined (NCCLS, 1993).

\section{Results}

\subsection{Organoleptic characters}

Organoleptic characters were evaluated in TC and PC (Table 1). The taste of the TC is pungent and astringent in PC. The colour noted as brown and muddish brown in TC and PC, respectively.

Table 1: Organoleptic characters of methanolic extract of TC and PC

\begin{tabular}{|c|l|l|l|}
\hline S.No. & Organoleptic characters & \multicolumn{1}{|c|}{ TC } & \multicolumn{1}{|c|}{ PC } \\
\hline 1. & Appearance & Fine powder & Granulated \\
3. & Taste & Pungent & Astringent \\
4. & Color & Brown & Muddish brown \\
5. & Odour & Pleasant & Pleasant \\
\hline
\end{tabular}

3.2 Preliminary phytochemical analysis

Preliminary phytochemical screening of methanolic extract of TC and PC revealed the presence of phytochemicals that is represented in Table 2. Alkaloids and phenols were found to be the major phytoconstituent in methanolic extract of TC and in PC, the flavonoids were found as main constituent.

3.3 In vitro antioxidant activity of methanol extract of Thirikadugu chooranam and Parangipattai chooranam

DPPH radical scavenging activity of two polyherbal formulations were given in the Figure 1. The DPPH radical scavenging activity test has been widely used to assess the in vitro antioxidant properties. Among the two investigated polyherbal formulations, 
TC showed highest DPPH radical scavenging power than PC. TC showed the $\mathrm{IC}_{50}$ value $2280 \mu \mathrm{g} / \mathrm{ml}$, whereas PC showed the $\mathrm{IC}_{50}$ value of $2940 \mu \mathrm{g} / \mathrm{ml}$.

Table 2: Qualitative phytochemical screening of TC and PC

\begin{tabular}{|c|c|c|c|c|}
\hline S.No. & Test & $\begin{array}{l}\text { Test applied } \\
\text { /reagent used }\end{array}$ & TC & $\mathbf{P C}$ \\
\hline \multirow[t]{2}{*}{1.} & \multirow[t]{2}{*}{ Alkaloids } & a) Dragendorff's & ++ & + \\
\hline & & b) Mayer's & +++ & + \\
\hline 2. & Saponins & Foam test & - & + \\
\hline 3. & Phytosterols & Salkowski's test & ++ & + \\
\hline 4. & Phenols & a) $10 \%$ lead acetate solution & +++ & + \\
\hline 5 . & Tannins & b) $1 \%$ gelatin containing & - & ++ \\
\hline & & $10 \% \mathrm{NaCl}_{2}$ & & \\
\hline 6. & Flavonoids & Alkaline reagent test & + & +++ \\
\hline
\end{tabular}

+Mild, ++ Moderate, +++High

The superoxide radical scavenging activity of the herbal formulations were depicted in the Figure 2. TC showed to be very high in scavenging superoxide radicals when compared to PC which shows the $\mathrm{IC}_{50}$ value of $2230 \mu \mathrm{g} / \mathrm{ml}$ and $2860 \mu \mathrm{g} / \mathrm{ml}$, respectively. Hydrogen peroxide scavenging activity of methanolic extract of two polyherbal formulations were presented in Figure 3. TC exhibited prominent hydrogen peroxide scavenging activity (2010 $\mu \mathrm{g} / \mathrm{ml}$ ) and in PC poor inhibition is noted in scavenging hydrogen peroxide with $\mathrm{IC}_{50}$ value $(3100 \mu \mathrm{g} / \mathrm{ml})$.

The antimicrobial activity of methanolic extract of TC and PC was tested against two gram-negative bacteria, Escherichia coli, Pseudomonas aeruginosa, two gram-positive bacteria, Staphylococcus aureus, Bacillus subtilus and the antifungal activity against Candida albicans, Aspergillus niger (Table 3). The methanol extract of PC showed maximum zone of inhibition at a concentration of $1000 \mu \mathrm{g} / \mathrm{ml}$ against gram-positive bacteria with $9.4 \mathrm{~mm}$ for Bacilli subtilus, $8.9 \mathrm{~mm}$ for Staphylococcus aureus, followed by $7.4 \mathrm{~mm}$ for E.coli, and $8.4 \mathrm{~mm}$ for Pseudomonas aeruginosa. In TC the zone of inhibition is $7.8 \mathrm{~mm}$ for Bacillus subtilus, $7.2 \mathrm{~mm}$ for Staphylococcus aureus, $6.5 \mathrm{~mm}$ for E.coli and $6.1 \mathrm{~mm}$ for Pseudomonas aeruginosa. No remarkable zone of inhibition was observed at $250 \mu \mathrm{g} / \mathrm{ml}$ of both the extracts. The maximum zone of inhibition for methanol extract of PC for Aspergillus niger and Candida albicans was found to be $4.45 \mathrm{~mm}$ and $5.31 \mathrm{~mm}$ respectively at a concentration of $1000 \mu \mathrm{g} / \mathrm{ml}$ whereas in TC, 2.2 $\mathrm{mm}$ and $3.2 \mathrm{~mm}$ zone of inhibition at $1000 \mu \mathrm{g} / \mathrm{ml}$ concentration is noted. There is no inhibition observed at 250 and $500 \mu \mathrm{g} / \mathrm{ml}$ concentrations. The zone of inhibition of PC was found to be maximum than TC which shows the antimicrobial activity of TC is lower than PC.

Table 3: In vitro antimicrobial activity on methanol extracts TC and PC

\begin{tabular}{|c|c|c|c|c|c|c|c|c|}
\hline \multirow{3}{*}{ S.No. } & \multirow{3}{*}{$\begin{array}{l}\text { Methanol } \\
\text { extracts }\end{array}$} & \multirow{3}{*}{$\begin{array}{l}\text { Conc. } \\
\text { g/ml }\end{array}$} & \multicolumn{6}{|c|}{ Zone of inhibition in $\mathrm{mm}$} \\
\hline & & & \multicolumn{4}{|c|}{ Bacteria } & \multicolumn{2}{|c|}{ Fungi } \\
\hline & & & Ec & $\mathbf{P a}$ & B s & $\mathbf{S a}$ & An & $\mathbf{C a}$ \\
\hline \multirow[t]{3}{*}{1} & \multirow[t]{3}{*}{$\mathrm{TC}$} & 250 & $3.2 \pm 0.12$ & $2.3 \pm 0.12$ & $3.4 \pm 0.12$ & $1.2 \pm 0.73$ & - & - \\
\hline & & 500 & $5.2 \pm 0.32$ & $4.2 \pm 0.73$ & $6.0 \pm 0.24$ & $5.2 \pm 0.82$ & & \\
\hline & & 1000 & $6.5 \pm 1.00$ & $6.1 \pm 1.02$ & $7.8 \pm 0.82$ & $7.2 \pm 0.34$ & $2.2 \pm 0.32$ & $3.2 \pm 0.12$ \\
\hline \multirow[t]{3}{*}{2} & \multirow[t]{3}{*}{$\mathrm{PC}$} & 250 & $2.2 \pm 0.6$ & $3.44 \pm 0.45$ & $2.61 \pm 0.09$ & $3.83 \pm 0.6$ & - & - \\
\hline & & 500 & $4.6 \pm 0.24$ & - & - & $4.53 \pm 0.53$ & - & - \\
\hline & & 1000 & $7.4 \pm 0.32$ & $8.45 \pm 0.89$ & $9.45 \pm 0.81$ & $8.95 \pm 0.31$ & $4.45 \pm 0.13$ & $5.31 \pm 0.52$ \\
\hline
\end{tabular}

Values are mean \pm SD of three replicate.

Ec-Escherichia coli; Sa-Staphylococcus aureus; Pa-Pseudomonas aeruginosa; Bs-Bacillus sps.; An-Aspergillus niger; Ca-Candida albicans.

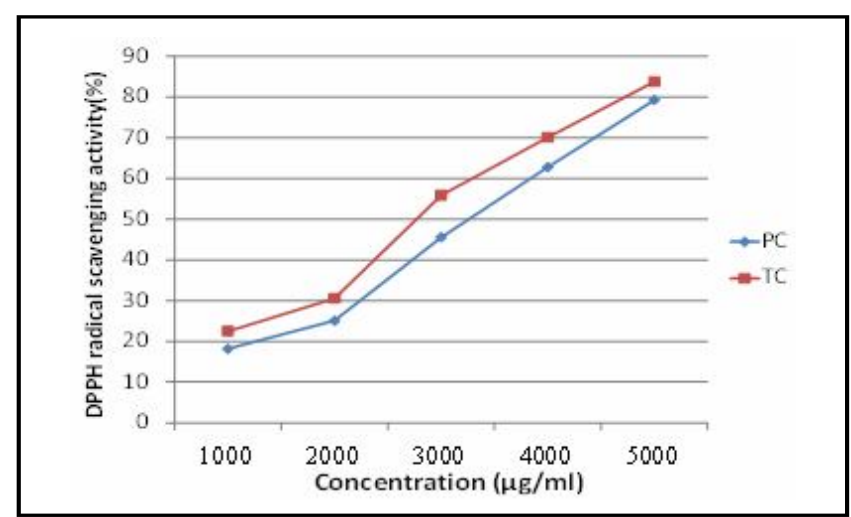

Figure 1: DPPH radical scavenging activity.

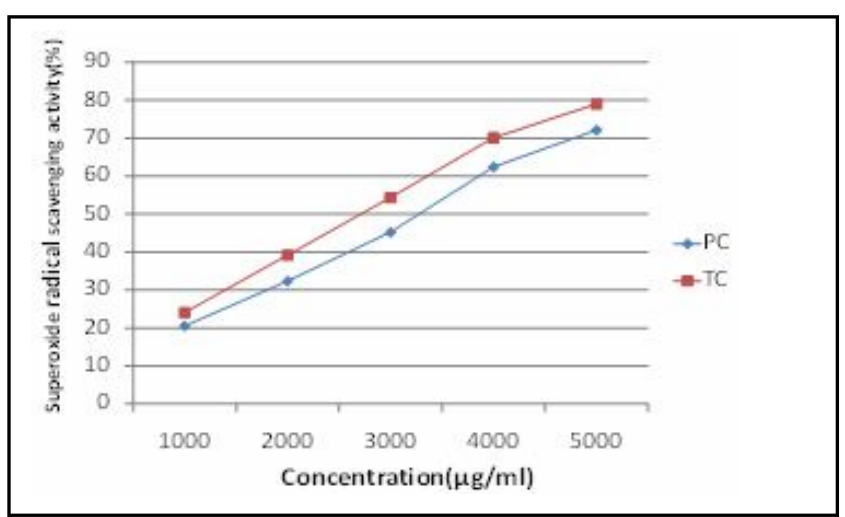

Figure 2: Superoxide radical scavenging activity. 


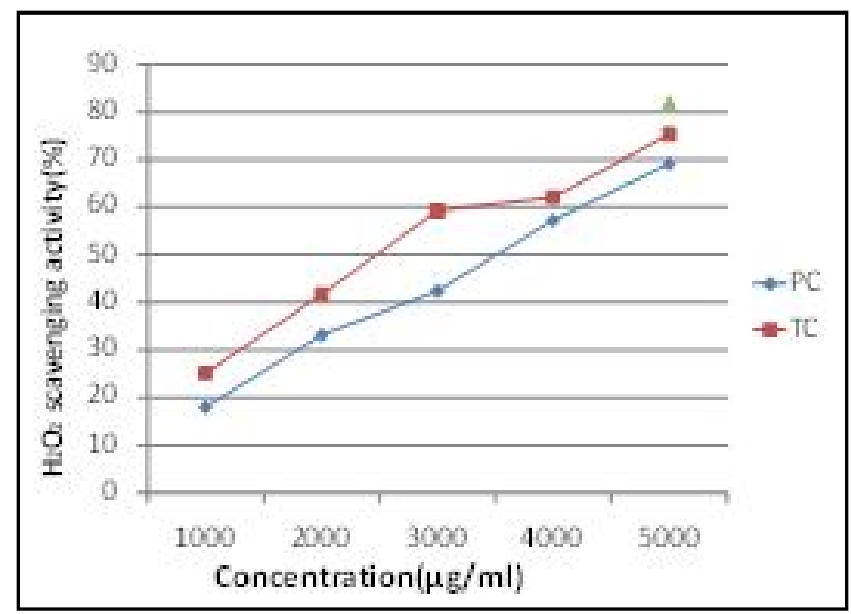

Figure 3: Hydrogen peroxide scavenging activity.

\section{Discussion}

Traditional systems of medicine have been in use for treating various ailments in many countries and practiced mostly in southern part of the world for curing even chronic conditions. Infectious diseases are main reason for disability, death and further distressingly it excessively affects developing countries, which is mainly attributed to poor quality of air. In traditional system of medicine, Thirikadugu chooranam is prescribed for all types of fever and pain (Kumar et $a l ., 2011)$ and Parangipattai chooranam is indicated for all types of skin diseases as leprosy, leukoderma and other venereal diseases (Thas, 2008).

The current study showed the presence of alkaloids, saponins, phytosterols, phenols, tannins and flavonoids in the methanolic extract of TC and PC and it also coexist with the previous researches (Ahmed et al., 2017; Barry et al., 1970; Cruickshank et al., 1975; Mirghani et al., 2020). Also, several studies reported that phenolic compounds were linked with antioxidant activity and take part an imperative role in lipid peroxidation (Yen et al., 1993; Malik et al., 2020). The secondary metabolites in the herbal extracts have profound antimicrobial and antioxidant activity (Wali et al., 2019). Hence the current research focuses on the evaluation of antimicrobial and antioxidant activity of the herbal formulations.

Due to increasing public concern about hygiene, many studies have been driving to investigate microbial resistance against infectious diseases. Among the microorganisms that represent a major health hazard, Staphylococcus aureus is highlighted as the bacteria responsible for illness in humans (Adhikari et al., 2012). The genus Candida, fungal pathogens also has proven relevance for a variety of infections, from superficial to invasive diseases (Kim and Sudbery 2011). The antimicrobial activity of the methanolic extracts were determined and the findings suggested that PC and TC were found to posseses antibacterial activity in which PC showed significant antibacterial activity against gram-positive bacteria than gram-negative and fungal strains. The presence of important secondary metabolites detected in the herbal extract are well known to have significant inhibitory action against bacteria and fungi (Hayek et al., 2013). These findings justify that the PC extract showed highest antimicrobial activity than TC.
Several previous studies have reported that plant extracts are usually more active against gram-positive bacteria due to structural differences in the cell wall than gram-negative bacteria. The vanity of plant compounds towards gram-negative pathogens has been proposed to be strongly related to efflux pumps (Tegos and George et al., 2002). Our reports also suggested that the PC showed significant antibacterial activity against gram-positive bacteria than gram negative-bacteria. On the other hand, extracts had not shown an efficacy against Aspergillus niger and Candida albicans as good as that observed for the gram-positive bacteria. Similar to this, the lack of antifungals and the increasing microbial resistance (Odom, 2014) also make the present reports relevant and important.

Reactive oxygen species (ROS) can cause consequential chemical destruction to DNA, proteins and unsaturated lipids which results in cell death (Fang 2002; Penget et al., 2014; Li et al., 2015). The increase ingestion of exogenous antioxidants would improve the damage caused by oxidative stress through inhibiting the proliferation of oxidative chain reaction, acting as free radical scavengers, quenchers of singlet oxygen and reducing agents (Baiano and del Nobile, 2015). Phenolic compounds such as phenolic acids, flavonoids, tannins, stilbenes, and anthocyanins have been extensively used as safe, valuable and imperishable sources of natural antioxidants (Manach, 2004).

In the present study, the antioxidant activity of TC and PC has been evaluated in vitro via 2, 2-diphenyl-1-picrylhydrazyl (DPPH) method, superoxide anion scavenging, hydroxyl radical scavenging activity. Superoxide is produced in the body by the addition of a single electron to oxygen and by several mechanisms, it is produced and hydrogen peroxide is produced by spontaneous dismutation reaction in the biological system. In the two investigated samples, TC has potent antioxidant activity than PC might be due to the presence of high phenolic content .The above results correlates with the study that the phenylpropanoids, 6-gingerol, 6-shogaol, flavonoid, quercetin as well as phenolic compounds in Zingiber officinale which is responsible for chemopreventive properties against oxidative stress and cancer by activating the Nrf2-ARE signalling pathways in human cells (Akinyemi et al., 2013; Hosseinzadeh et al., 2017. Romero et al., 2018; Peng et al., 2015). Another report also supports with the above study that the methanolic extracts of leaves of A. precatorius possess proficient antioxidant activity which might be owing to elevated phenolic content (Modi et al., 2018).

\section{Conclusion}

People believe that herbal drugs are safer than synthetic medications as they are obtained from natural sources and it is used as an substitute for the management of several diseases, mainly for diseases due to lifestyle modifications that needs permanent medications. Traditional therapeutic practitioners also trust that the phytoconstituents in herbal drug have good compatability with the human being, but this can only be possible by implementation of good practices in manufacturing and quality control.

With the advancement in current technology, the concept of active marker recognition and quantification can be useful in the progression of standardization. Considering this present situation, focus on the development of standardized formulation and identification of bioactive phytocompounds followed by assessment through clinical trial is much needed. 


\section{Acknowledgements}

We express our sincere thanks to the Management, and the Principal, Nandha Educational Institutions, Erode, Tamilnadu, India for their constant support and encouragement throughout the study.

\section{Conflict of interest}

The authors declare no conflicts of interest relevant to this article.

\section{References}

Adhikari, R. P.; Ajao, A. O.; Aman, M. J.; Karauzum, H.; Sarwar, J.; Lydecker, A. D. and Roghmann, M. C. (2012). Lower antibody levels to Staphylococcus aureus exotoxins are associated with sepsis in hospitalized adults with invasive $S$. aureus infections. The Journal of Infectious Diseases, 6(6): $915-923$.

Ahmed, S. and Ibrahim, M. (2017). Chemical investigation and antimicrobial activity of Francoeuria crispa (Forssk) Grown Wild in Egypt. Reviews, pp: 114

Akinyemi, A. J.; Ademiluyi, A. O. and Oboh, G. (2013). Aqueous extracts of two varieties of ginger (Zingiber officinalO) inhibit angiotensin converting enzyme, iron (II): And sodium nitroprusside-induced lipid peroxidation in the rat heart in vitro. Journal of Medicinal Food, 16(7):641-646.

Baiano A.and del Nobile M.A.( 2015). Antioxidant compounds from vegetable matrices: Biosynthesis, occurrence, and extraction systems. Crit. Rev. Food Sci. Nutr., 56:2053-2068.

Barry, A. L.; Garcia, F. and Thrupp, L. D. (1970). Interpretation of sensitivity test results. American Journal of Clinical Pathology, 53:140-144.

Cruickshank, R.; Duguid, J.; Marmion, B. P. and Swain, R. H. (1975). Medical Microbiology (12th edn) Churchill Livingstone.

Fang, Y. Z. (2002). Sheng YANG a Guoyao WU. Free radicals, antioxidants, and nutrition. Nutrition [online], 18(10):872-879.

Hayek S. A.; Gyawali, R. and Ibrahim S. A. (2013). Antimicrobial natural products in microbial pathogens and strategies for combating them: Science, technology and education, ed Méndez-Vilas A. (Badajoz: FORMATEX), pp:910-921.

Hosseinzadeh, A.; Juybari, K. B.; Fatemi, M. J.;Kamarul, T.; Bagheri, A.; Tekiyehmaroof, N.and Sharifi, A. M. (2017). Protective effect of ginger (Zingiber officinale Roscoe) extract against oxidative stress and mitochondrial apoptosis induced by interleukin-1 $\beta$ in cultured chondrocytes. Cells Tissues Organs, 204(5-6):241-250.

Jothivel, N.; Ponnusamy, S. P.; Appachi, M.; Singaravel, S; Rasilingam, D. Deivasigamani, K.and Thangavel, S. (2007). Antidiabetic activity of methanol leaf extract of Costus pictus D. Don in alloxan-induced diabetic rats. Journal of Health Science, 53(6):655-663.

Kim, J. and Sudbery, P. (2011). Candida albicans, a major human fungal pathogen. The Journal of Microbiology, 49(2):171-177.

Kokate, C.K. (2002). Practical pharmacognosy.Fifth edition.

Kumar, G.; Karthik, L. and Rao, K. B. (2011). A review on pharmacological and phytochemical properties of Zingiber officinale Roscoe (Zingiberaceae). Journal of Pharmacy Research, 4(9):2963-2966.

Li, S.; Tan, H. Y.; Wang, N.; Zhang, Z. J.; Lao, L.; Wong, C. W. and Feng, Y. (2015). The role of oxidative stress and antioxidants in liver diseases. International Journal of Molecular Sciences, 16(11):26087-26124.

Malik, T.; Madan, V. K. and Prakash, R. (2020). Herbs that heal: Floristic boon to the natural healthcare system. Ann. Phytomed., 9(2):6-14.
Manach, C.; Scalbert, A.; Morand, C.; Rémésy, C. and Jiménez, L. (2004). Polyphenols: Food sources and bioavailability. The American journal of Clinical Nutrition, 79(5):727-747.

Mirghani, M.; Osman, W.; Garelnabi, E. A.; Mohammed, M. S. and Ali, O. H. (2020). Pulicaria crispa (Forssk) Oliv: A review of ethnopharma-cology, phytochemistry and biological activities. Khartoum Journal of Pharmaceutical Sciences, 1(1):110-120.

Modi, C. M., Ladumor, V. C., Patel, U. D., Patel, H. B., Solanki, S. L. and Bhadarka, D. H. (2018). Phytochemical analysis and comparative study of in vitro free radical scavenging activity of different extracts of leaves of Abrus precatorius L. Anna. of Phytomedicine., 7(2):133-137.

Nakamura, Y.; and Arakawa, H. (2017). Discovery of Mieap regulated mitochondrial quality control as a new function of tumor suppressor p53. Cancer Science., 108(5):809-817.

National Committee for Clinical Laboratory Standards (1993). Methods for Dilution Antimicrobial Susceptibility Test for Bacteria that Grow Aerobically; Approved Standard Ml-A3. NCCLS, Villanova, PA.

Odom, A. R. (2014). The triphenylethylenes, a novel class of antifungals. M. Bio., 5(3):e01126-1134.

Parham, S.; Wicaksono, D. H.; and Nur, H. (2019). A proposed mechanism of action of textile/A12O3-TiO2 bimetal oxide nanocomposite as an antimicrobial agent. The Journal of The Textile Institute, 110(5): 791-798.

Peng, C.; Wang, X.; Chen, J.; Jiao, R.; Wang, L.; Li, Y. M. and Chen, Z. Y. (2014). Biology of ageing and role of dietary antioxidants. Bio. Med. Research International, pp: 140 .

Peng, S.; Yao, J.; Liu, Y.; Duan, D.; Zhang, X. and Fang, J. (2015). Activation of Nrf2 target enzymes conferring protection against oxidative stress in PC12 cells by ginger principal constituent 6-shogaol. Food and Function, 6(8):2813-2823.

Romero, A., Forero, M., Sequeda-Castañeda, L. G., Grismaldo, A., Iglesias, J., CelisZambrano, C. A. and Morales, L. (2018). Effect of ginger extract on membrane potential changes and AKT activation on a peroxideinduced oxidative stress cell model. Journal of King Saud UniversityScience, 30(2):263-269.

Ruch, R. J.; Cheng, S. J. and Klaunig, J. E. (1989). Prevention of cytotoxicity and inhibition of intercellular communication by antioxidant catechins isolated from Chinese green tea. Carcinogenesis, 10(6): 1003-1008.

Sánchez-Moreno, C.; Larrauri, J. A.; and Saura Calixto, F. (1998). A procedure to measure the antiradical efficiency of polyphenols. Journal of the Science of Food and Agriculture, 76(2):270-276.

Simões, D.; Miguel, S. P.; Ribeiro, M. P.; Coutinho, P.; Mendonça, A. G. and Correia, I. J. (2018). Recent advances on antimicrobial wound dressing: A review. European Journal of Pharmaceutics and Biopharmaceutics, 127:130-141.

Tegos and George. (2002). Multidrug pump inhibitors uncover remarkable activity of plant antimicrobials. Antimicrobial agents and Chemotherapy, 46(10):3133-3141.

Thas, J. J. (2008). Siddha medicine-background and principles and the application for skin diseases. Clinics in Dermatology, 26(1):62-78.

Torkan, S.; Khamesipour, F. and Katsande, S. (2015). Evaluating the effect of oral administration of Echinacea hydroethanolic extract on the immune system in dog. Autonomic and Autacoid Pharmacology, 35: 9-13. 
Tribess, B.; Pintarelli, G. M.; Bini, L. A.; Camargo, A.; Funez, L. A.; de Gasper, A. L. and Zeni, A. L. B. (2015). Ethnobotanical study of plants used for therapeutic purposes in the Atlantic Forest region, Southern Brazil. Journal of Ethnopharmacology, 164:6-146.

Wali,A. F.; Hamad, E.A.; Khazandar,A.A.; Al-Azzawi, A. M.; Sarheed, O. A.; Menezes, G. A.and Alam, A. (2019). Antimicrobial and in vitro antioxidant activity of Salvia officinalis L. against various re-emergent multidrug resistance microbial pathogens. Anna. of Phytomedicine., 8(2):115120 .

Yen, G. C.; Duh, P. D. and Tsai, C. L. (1993). Relationship between antioxidant activity and maturity of peanut hulls. Journal of Agricultural and Food Chemistry, 41(1):67-70.

Zhishen, Jia; Tang Mengcheng and Wu Jianming (1999). The determination of flavonoid contents in mulberry and their scavenging effects on superoxide radicals. Food Chemistry, 64(4):555-559. 